BRICKWORK 3

AND ASSOCIATED STUDIES 


\section{Related volumes}

$\left.\begin{array}{l}\text { Brickwork } 1 \text { and Associated Studies } \\ \text { Brickwork } 2 \text { and Associated Studies }\end{array}\right\} \quad$ Harold Bailey and David Hancock

Other title of interest

The Skills of Plastering, Mel Baker 


\title{
BRICKWORK 3 \\ AND ASSOCIATED STUDIES
}

\author{
Harold Bailey \\ Sometime Senior Lecturer \\ Stockport College of Technology \\ David Hancock \\ Senior Lecturer \\ Stockport College of Technology
}

Second Edition

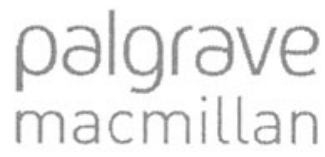


(C) (The estate of) H. Bailey and D. W. Hancock 1979, 1990

All rights reserved. No reproduction, copy or transmission of this publication may be made without written permission.

No paragraph of this publication may be reproduced, copied or transmitted save with written permission or in accordance with the provisions of the Copyright, Designs and Patents Act 1988 , or under the terms of any licence permitting limited copying issued by the Copyright Licensing Agency, 33-4 Alfred Place, London WC1E 7DP.

Any person who does any unauthorised act in relation to this publication may be liable to criminal prosecution and civil claims for damages.

First published 1979

Reprinted 1987, 1989

Second edition 1990

Reprinted 1990

Published by

MACMILLAN EDUCATION LTD

Houndmills, Basingstoke, Hampshire RG21 2XS

and London

Companies and representatives

throughout the world

British Library Cataloguing in Publication Data

Bailey, Harold

Brickwork.-2nd ed.

Vol. 3

1. Brickwork

I. Title II. Hancock, David III. Bailey, Harold

Brickwork and associated studies

$693^{\prime} .21$

ISBN 978-0-333-51957-8

ISBN 978-1-349-11381-1 (eBook)

DOI 10.1007/978-1-349-11381-1

This book is printed on paper suitable for recycling and made from fully managed and sustained forest sources. Logging, pulping and manufacturing processes are expected to conform to the environmental regulations of the country of origin. 


\section{CONTENTS}

Preface

\section{Safety on Site}

Safety on site

Accident procedure

After an accident

Keeping records

The Health and Safety at Work

Act 1974

Safety equipment

Some further points

Protection of eyes

First aid

Protection of the public

2. Decorative and Functional Features

String, dentil and dog-tooth courses

Decorative treatment of quoins

Pattern walling

Decorative brick panels

Bonding plinth courses

Corbelling brickwork

Tumbling-in

\section{Reinforced Brickwork}

Types of reinforcement

Positioning of reinforcement

\section{Step Construction}

Requirements for brick and concrete steps

\section{Drainage}

Subsoil drainage

General principles of drainage

Drainage systems vii

1

1

1

1

2

2

2

2

2

3

4

6
Ventilation of drains $\quad 48$

Inspection chambers $\quad 50$

Setting out and laying drains $\quad 51$

Testing drains 51

Repairs and alterations to drains $\quad 54$

Calculation of invert levels $\quad 56$

6. Scaffolding 60

Construction Regulations $\quad 60$

Tubes, fittings and boards $\quad 60$

Types of scaffold $\quad 66$

Ladders $\quad 73$

Lifting equipment $\quad 73$

7. Maintenance, Repair and Fixing Equipment 84

Replacing defective firebacks $\quad 84$

Defective chimney stacks $\quad 86$

Defective brick-on-edge window sill $\quad 89$

Repointing old buildings $\quad 90$

Alteration to wall lengths and thicknesses $\quad 92$

Increasing the thickness of existing walls 94

Fixing cantilever brackets $\quad 95$

Fixing rag bolts $\quad 95$

8. Paving 99

Types of paving slab $\quad 99$

Brick paving $\quad 101$

$\begin{array}{ll}\text { Compound paving } & 107\end{array}$

9. Quantities of Materials 108

Bricks and mortar $\quad 108$

English and Flemish bonds $\quad 112$

Blocks and mortar $\quad 112$

Volumes of concrete $\quad 114$

Dry material requirements $\quad 115$

Number of floor tiles or paving slabs $\quad 116$

Bricks for paving

48

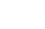

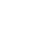

54

56

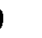

60

60

3

84

8

6

9

9

5


vi Contents

Some Useful Conversion Factors

Multiple Choice Questions
121 Answers to Multiple Choice Questions

130

$122 \quad$ Index 


\section{PREFACE}

This series of three volumes is designed to provide an introduction to the brickwork craft and the construction industry for craft apprentices and all students involved in building. All too often, new entrants to the construction industry are expected to have a knowledge of calculations, geometry, science and technology irrespective of their previous education. It is the authors' aim to provide a course of study which is not only easily understood but is also able to show the relationship that exists between technology and associated studies.

The construction industry recognises that the modern craftsman, while maintaining a very high standard of skills, must be capable of accepting change - in methods, techniques and materials. Therefore it will be necessary for apprentices to develop new skills related to the constant advancements in technology.

This third volume concludes the complete Craft Certificate course for the City \& Guilds of London Institute, and includes the many other areas of work in which the craftsman is required to demonstrate his ability.

To become a highly skilled technician in the modern construction industry, the apprentice should recognise that physical skills must be complemented by technology, and that planned methods of construction must be used in all work situations.

The apprentice and young craftsman will be able to appreciate the diversity of the bricklayer's craft, and to relate his own abilities and ambitions to the immense scope offered by today's construction industry.

\section{H. BAILEY D. W. HANCOCK}

\section{ACKNOWLEDGEMENTS}

The authors wish to acknowledge the assistance and cooperation of: The Clay Pipe Development Association Ltd, for figures 5.19, 5.20 and 5.21; S.G.B. Scaffolding (Great Britain) Ltd, for figures 6.6 to 6.21, 6.29 and 6.33; Hilti Ltd for figures 6.26, 6.27 and 6.28; The Brick Development Association, for figure 6.30; Walter Somers (Materials Handling) Ltd, for figures $6.40,6.41$ and 6.42 . 